\title{
Aesthetics in Cartographic Epistemology
}

\author{
Chelsea Nestel ${ }^{\text {a }}$ \\ a University of Wisconsin-Madison (USA),nestel@wisc.edu
}

Keywords: Art in Cartography, Theoretical Cartography, Map Design

What is cartographic aesthetics? In this presentation, I will discuss aspects of my research into the definition question in response to Kent's 2005 paper, “Aesthetics: A Lost Cause In Cartographic Theory?” First, I will explain some aesthetic concepts from philosophy and their application to cartographic epistemology, explaining how cartography is already practicing and conducting research into aesthetics. Then, I will suggest some avenues for how we might expand cartographic aesthetic epistemology. Predecessors to this work are Kent (2018, 2017, esp. 2005), Dodge, Kitchin and Perkins (2011), and Denil (2012). Given the place of aesthetics and design at the heart of modern cartography, disambiguating aesthetics from terms like "beauty" and "design" is more than a semantics problem. Instead, it is an epistemological problem, with historical, intellectual, educational, and even existential dimensions, which I discuss in this presentation.

In cartography, aesthetic discussions center around the functional "art" or the "beauty" of the map product (Kent 2018 , Woodruff 2012; Tyner 2014, Imhof 1982, Robinson 1952, Raisz 1948, etc.). Other authors have associated aesthetics with scientific elegance (Robinson 1952, if indirectly), a map's functional and communicative qualities (Kent 2005), its "truth," and the clarity or cohesion of a map (Imus and Loftin 2012, Imhof 1982). Dodge, Kitchin and Perkins (2011) describe cartographic aesthetics as cartographic scientific aesthetics, which uses semiotics and psychological understandings of perception.

I suggest that a simple way to understand aesthetics is to think of aesthetics as special kinds of experiences, distinct from everyday, nonaesthetic experiences. Or, to put it even more simply, aesthetic experiences are "those experiences that we really care about" (Nanay 2015). First, I explain the difference between aesthetics and art. While aesthetics can involve art, aesthetics is not the same as the philosophy of art. Moreover, one can have an aesthetic experience without engaging with artwork (or, conversely, fail to have an aesthetic experience from perceiving a work of art). This simple definition of aesthetic as special experiences encompasses a wide range of aesthetic concepts within philosophy that cartographers, who wish to create "beautiful" map products, should care about, too, by considering the question "how is a map experienced as beautiful?"

Following Shelley (2020), aesthetic concepts touched on in this presentation will include aesthetic judgment, aesthetic attitudes, aesthetic objects, aesthetic experience, and aesthetic value. Although these aesthetic concepts are unfamiliar to many cartographers, academic cartography has engaged with these concepts without realizing it. I will begin placing cartographic aesthetic epistemology within these concepts. Thus, the purpose of this presentation is to begin translating these aesthetic concepts to help cartography see 1.) the range of its existing aesthetic epistemology, which is expansive, and 2.) move towards an expanded cartographic aesthetic theory. I will conclude by walking through a case study to show how expanding cartographic aesthetic theory opens new opportunities for cartography.

\section{References:}

Denil, M. 2012. "A Disquisition on Cartographic Style and Taste: with Attendant Remarks upon Aesthetics, Clarity, Design, and Mapicity." Cartographic Perspectives. 73. https://cartographicperspectives.org/index.php/journal/article/view/cp73-denil/html

Dodge, Kitchin and Perkins. 2011. Introductory Essay: Cartographic Aesthetics and Map Design. In The Map Reader, eds. Dodge, Kitchin and Perkins, 194-200. Oxford: John Wiley and Sons.

Imhof, E. 1982. Cartographic Relief Presentation. Redlands: ESRI Press.

Imus, D. and Loftin, P. 2012. “The Beauty of Clear Communication.” Cartographic Perspectives. 73. https://cartographicperspectives.org/index.php/journal/article/view/cp73-imus-loftin/html.

Kent, A. 2018. Cartographic Aesthetics. In The Routledge Handbook of Mapping and Cartography, eds. Kent and Vujakovic. 299-310. New York: Routledge.

2017. Cartographic Style and the Aesthetic Fix. The Cartographic Journal. 54: 1, 1-4. https://doi.org/10.1080/00087041.2017.1291556

2005. Aesthetics: A Lost Cause in Cartographic Theory? The Cartographic Journal, 42: 2, 182-188, DOI: $10.1179 / 000870405 \times 61487$ 
Nanay, B. 2015. Aesthetics as Philosophy of Perception. Oxford: Oxford University Press.

Raisz, E. 1948. General Cartography. McGraw-Hill Publishers.

Robinson, A. H. 1952. The Look of Maps. Madison: University of Wisconsin Press.

Shelley, J. 2020. "The Concept of the Aesthetic", In The Stanford Encyclopedia of Philosophy (Winter 2020 Edition), ed. Edward N. Zalta. https://plato.stanford.edu/archives/win2020/entries/aesthetic-concept/

Tyner, A. 2014. Principles of Map Design. Guilford Publications.

Woodruff, A. 2012. The Aesthetician and the Cartographer. https://www.axismaps.com/blog/the-aesthetician-and-thecartographer 